\title{
Occurrence and seasonal variation of heteroligus meles billb (Coleoptera: Dynastidae) in upper Niger Delta, Nigeria.
}

\author{
Tobih, Francis Okiemute \\ Dept of Agronomy, Delta State University, Asaba Campus, Asaba, Delta State, Nigeria. \\ e-mail: tobih002@yahoo.com

\begin{abstract}
Studies conducted in 2004/2005 in the rainforest ecological zone of Anwai-Asaba in the Upper Niger Delta, Nigeria, examined the occurrence and seasonal variation in the population of yam tuber beetles (Heteroligus spp). The beetle population started building up in May with the peak occurrence as determined by the light traps occurring in July-August. The population trend is climate dependent and the peak was unimodal. Correlation analysis was negative for temperature $(b=-0.662)$ while it was positively correlated with rainfall $(b=0.552)$ and relative humidity $(b=0.543)$. Based on the coefficient of determination $\left(R^{2}\right)$, beetle occurrence can be predicted on weather elements studied to about $52 \%$ for rainfall $29 \%$ relative humidity and $44 \%$ for temperature. The best predictive tools for monitoring the commencement of occurrence of the yam beetle are the three major weather parameters, namely temperature, relative humidity, rainfall but the later was more critical according to this study.
\end{abstract}

Keywords: Occurrence, Yam Beetle, Population, Niger Delta, Variation.

\section{INTRODUCTION}

Yams, Dioscorea spp. (Dioscoreae) make important contribution to the agricultural economy of most tropical countries that grow the crop. They are a staple carbohydrate food and income earner through trading in the commodity [7, 11]. Africa produces about 32.9 million metric tones of yam tubers annually (representing about $95 \%$ of world's output) and Nigeria alone contributes 28 million metric tones $[2,1]$. Recent report indicated Nigeria as the largest producer of yam in the world with annual production of 36.72 million metric tones out of the global total output of 51.49 million metric tones in 2006 [3]. Inspite of the important contributions of yam to the socio-economic life of the people, damage caused by yam beetles is a major constraint to higher tuber yield in Nigeria [14, 15]. Four major species of yam beetles have been reported in Nigeria, namely, Heteroligus meles Billb, $H$. appius Burm., Prionoryctes rufopiceus, Arrow and P. cannaliculus Arrow [14]. Heteroligus spp. are the commonest and most widely distributed. In the old Asaba province of Delta State, Nigeria, yam beetle damage was estimated at $20 \%$ [14]. More recent studies by [16] and [17,18] showed that yam beetle damage ranged from $31-51 \%$ resulting in $23-60 \%$ loss in tuber yield.

Various type of light traps are used to make phenological observations on insect species. They may be used for general or long-term studies on the diversity of a fauna of a particular group or species $[5,13]$. This study was undertaken to examine the occurrence and seasonal variation of this important soil insect of yam in Asaba area of upper Niger Delta of Nigeria.

\section{MATERIALS AND METHODS}

Study area: A two-year study (Jan, 2004-Dec 2005) to determine the occurrence and seasonal variation of yam beetle (Heteroligus spp) was carried out in Anwai-Asaba campus of Delta State University. The area is located at (latitude $06^{\circ} 14^{1}$ and longitude $06^{\circ}$ $49^{1} \mathrm{E}$ ) with a hot humid climate, mixed vegetation of forest interspersed with shrubs and grasses. The rainfall pattern is bi-modal with peaks in July and September $(1,505 \mathrm{~mm})$, mean temperature of $28 \pm 6^{\circ} \mathrm{C}$, relative humidity varies from $69-85 \%$ while the solar radiation is about 4.8 bars. (Nigerian Meteorological Agency, Delta State meteorological Inspectorate, Asaba, [10]

Ten 200-watt light traps were placed infront of randomly selected residential houses and classrooms very close to beetle breeding sites. The traps were monitored daily from 1830-1200h and the beetles attracted were collected daily from the ground or wall of building. Total collections from all traps were summed up monthly. Sample specimens of the adult beetles were sent to the Institute of Insect Museum, Department of Crop Protection, Ahmadu Bello University, Zaria, Nigeria for identification. Correlation 
analysis was used to determine the relationship between weather variables (temperature, rainfall and relative humidity) and beetle numbers while predictive equations were obtained by regression.

\section{RESULTS AND DISCUSSION}

The adult beetles were identified by comparison with paratypes as Heteroligus meles. Occurrence of the beetles commenced in May 2004 when the erstwhile high mean temperatures dropped from approximately $29^{\circ} \mathrm{C}$, and above to $28^{\circ} \mathrm{C}$ while the mean relative humidity increased from $79 \%$ to $85 \%$ in the same months and year under consideration. Similar upward increases were observed in the rainfall pattern for the same period. The number of adult beetles caught in the month of July and August were 205 and 350 individuals, representing $26 \%$ and $44.4 \%$ of the total adults caught in the 2004 sampling. (Fig1). The beetle peak population coincided with the period when the mean temperature was approximately $27^{\circ} \mathrm{C}$, relative humidity $86-88 \%$ while rainfall was between $213 \mathrm{~mm}-273 \mathrm{~mm}$ for the same months of July and August, respectively.
In (2005), (Fig 2) the occurrence of the yam beetle commenced in May when the mean temperature dropped from $31^{\circ} \mathrm{C}$ in April to $29^{\circ} \mathrm{C}$ while the mean relative humidity increased from $78 \%$ to $82 \%$ within the months and year under consideration; rainfall, however increased dramatically from $88 \mathrm{~mm}$ in April to $195 \mathrm{~mm}$ in May of 2005 sampling. The number of beetles attracted to light followed the same trend as in 2004 sampling where a total of 182 and 198 adult beetles representing $36.3 \%$ and $39.5 \%$ were trapped. Coincidentally, the mean temperature was $27^{\circ} \mathrm{C}$, relative humidity, $86-89 \%$ while rainfall ranged from $354 \mathrm{~mm}$ to $363 \mathrm{~mm}$ for the months of July and August in the year under consideration. The two-year samplings indicated that the occurrence and variation in the population of the yam beetle is weather dependent. Relative humidity and rainfall were positively correlated with beetle numbers but were not significant $(p \geq 0.05)$. . However, temperature was negatively correlated with beetle population but was not also significant at $5 \%$ probability (Table, $1 \mathrm{Fig} 3$ ).

Table 1: $\quad$ Pooled Correlation Coefficient between mean weather parameter and beetle population for 2004 and 2005

\begin{tabular}{|l|l|l|l|l|}
\hline \multicolumn{1}{|c|}{ Weather variables } & \multicolumn{1}{|c|}{$\begin{array}{c}\text { Mean annual } \\
\text { temperature }\left({ }^{0} \mathrm{C}\right)\end{array}$} & $\begin{array}{c}\text { Mean relative } \\
\text { humidity }\end{array}$ & \multicolumn{1}{|c|}{$\begin{array}{c}\text { Mean annual } \\
\text { rainfall (mm) }\end{array}$} & \multicolumn{1}{c|}{$\begin{array}{c}\text { Mean beetle } \\
\text { population }\end{array}$} \\
\hline Mean annual temperature $\left({ }^{0} \mathrm{C}\right)$ & 1 & 1 & & \\
\hline Mean \% relative humidity & $-0.652^{*}$ & $0.755^{\star *}$ & 1 & \\
\hline Mean annual rainfall (MM) & $-0.652^{*}$ & 0.543 & 0.552 & 1 \\
\hline Mean beetle population & -0.662 & & \\
\hline
\end{tabular}

* Correlation is significant at $5 \%$ probability level

${ }^{* *}$ Correlation is significant at $1 \%$ probability level.

The commencement of the adult beetles is synchronised with the planting season of yam in which temperature is usually low while rainfall and relative humidity are high, hence the correlation of these weather elements with beetle occurrence. This was equally reported by $[14,12]$ that yam beetle migrate principally for feeding and breeding purposes. Soil moisture regime and relative humidity was reported by [4], to cause positive response in banana weevils (Cosmopolites sordidus), because they are known to be highly vulnerable to desiccation. The observation appear true for yam beetles too as it prefers moist environment and good soil moisture with optimum relative humidity and rainfall. This result agreed with the studies of [8] on relative abundance of Cosmopolites sordidus conducted on plantain cropping system in Southeastern Nigeria. There, it was reported that weevil population is climate dependent with regards to temperature, rainfall and relative humidity. The peak population of the beetle in July/August for the two year studies corroborated earlier report by Tobih et al [17], where July/August was reported as the peak period for yam beetle population in Aniocha and Oshimili areas of Delta State, Nigeria. A good knowledge of population fluctuation of any insect pest is a necessary and useful tool in effective management decision according to Kumar (1984). It does appear from this study that the population density and rate of infestation of the beetle vary from year to year and place to place depending on the prevailing biotic and climatic factors $[19,14]$. 
Agric. Biol. J. N. Am., 2011, 2(5): 826-831

Yam beetles could only cause damages to yam tubers for a maximum periods of 6-7months (MayOctober) according to this investigation whereas other periods they are involve on breeding flight (Nov/Dec) or feeding flight, April/May each year [14] It was observed that no adult beetle was trapped during breeding periods. This may be due to their migration to the low land areas for hibernation in the case of $H$. appius and breeding purposes for $H$. meles [14]. The pooled regression curves for the weather parameters against beetle population are presented in figures $1 \mathrm{a}, 1 \mathrm{~b}$ and $1 \mathrm{c}$ while the pooled correlation coefficient between weather and beetle population is shown in Table1. The correlation analysis indicates an inverse relationship between temperature and beetle population where $b=-0.662$ (Table 1). Conversely, the same analysis indicated positive relationship for relative humidity $(b=0.543)$ and rainfall $(b=0.550)$, although they were not statistically significant $(p \geq 0.05)$.

The regression equation indicated that the weather elements can be used as a monitoring tool for commencement of beetle and their population. For example, about $52 \%$ forecast can be made for rainfall, $29 \%$ for relative humidity and $44 \%$ for temperature. However it is suggested that the study periods be increased to at least 10years for more accurate and reliable forecast to be made. Farmers in the study area are advised to plan their yam planting in such a way to avoid the tuberlization period coinciding with the peak population density of the yam beetle in July and August since more attack is likely to occur this period.

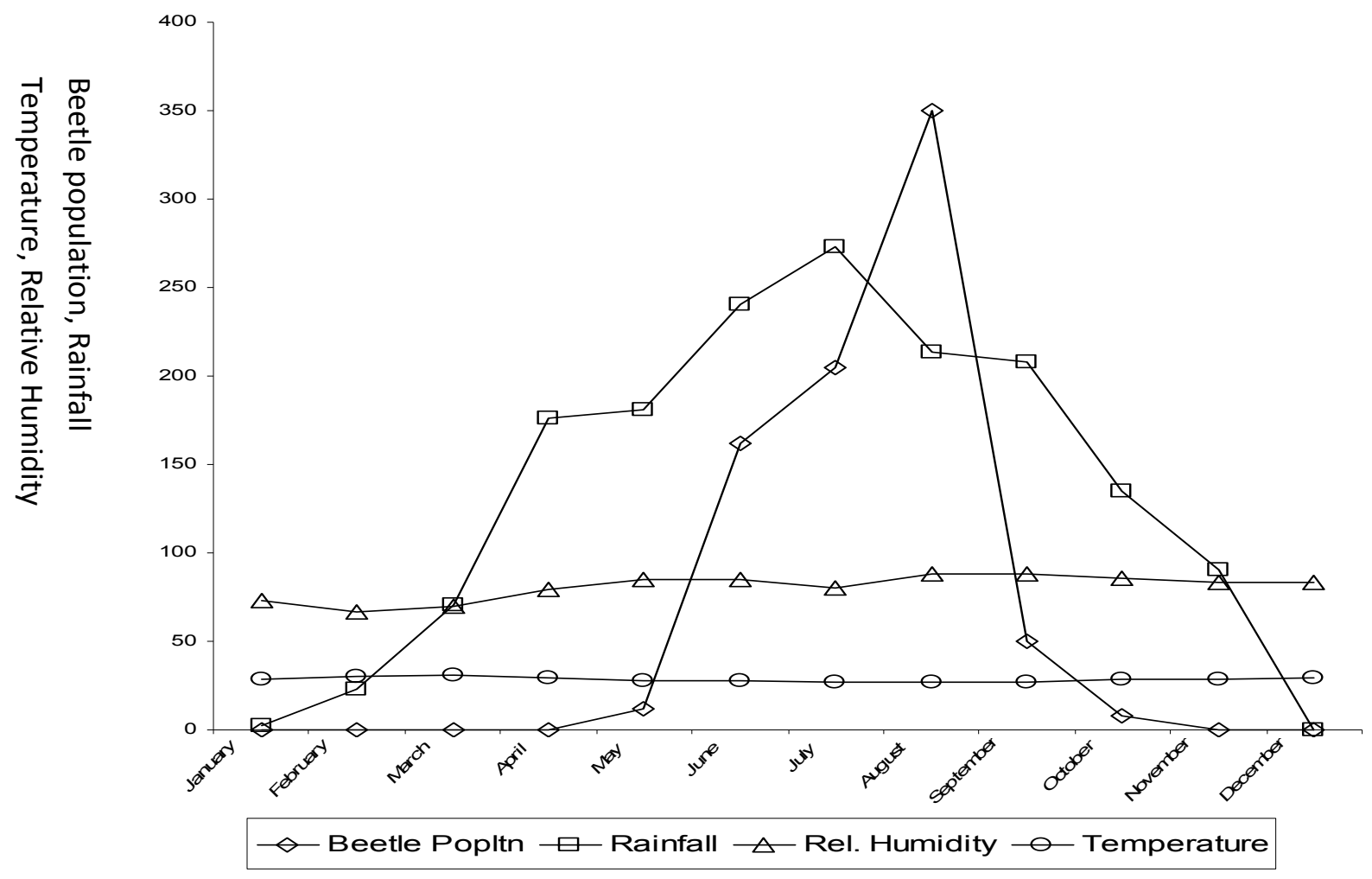

Fig 1: Distribution of beetle population and major weather parameters, 2004 


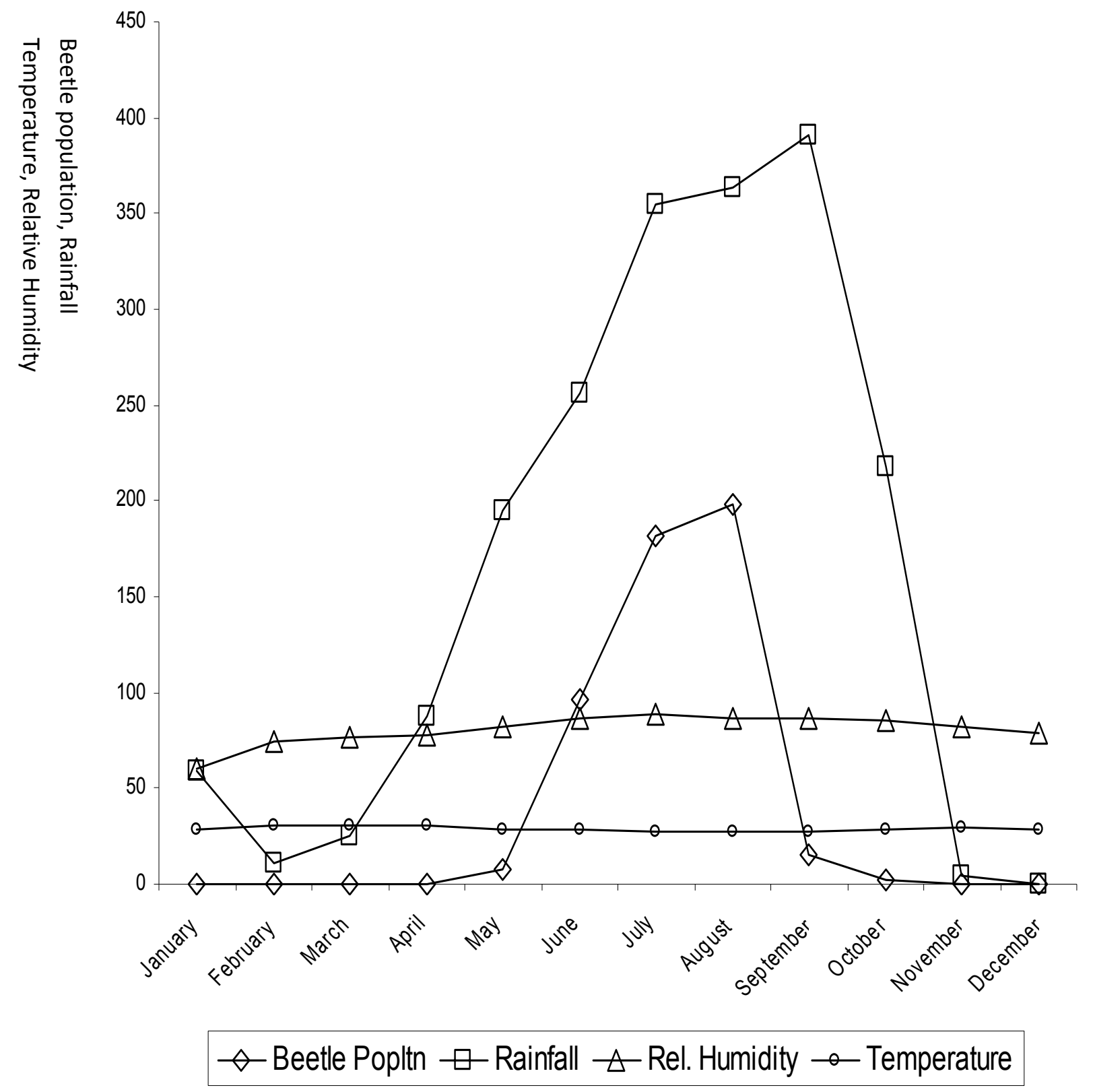

Fig 2: Distribution of beetle population and major weather parameters, 2005 
Agric. Biol. J. N. Am., 2011, 2(5): 826-831
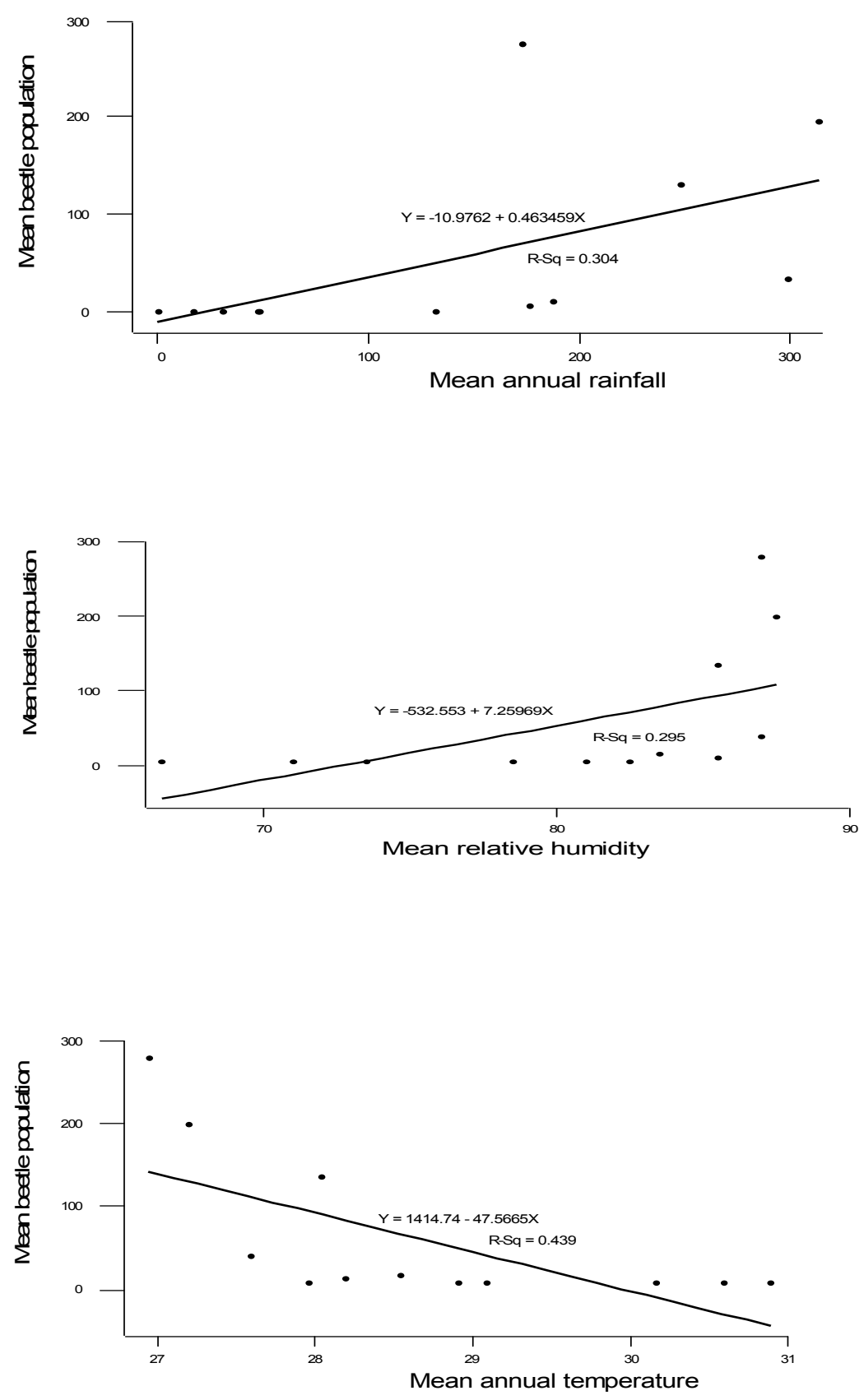

Fig 3: Relationship between beetle population and mean annual rainfall, relative humidity and temperature 


\section{REFERENCES}

[1] Central Bank of Nigeria. Nigeria Estimated Output of major Agricultural Commodities Annual Report Central Bank of Nigeria 2005, 131pp.

[2] FAO, Food and Agriculture Organisation of the United Nations, Rome Production Year Book. 1997, F.A.O. Rome.

[3] FAO Statistics Division Food and Agriculture Organisation Rome, Italy 2009.

[4] Frison E.A., Gold, C.S., Karamura, E.B., Sikora, R.A.. Integrated Pest Management: an overview in Frison, E.A., Gold C.S. Karamura, E.B. Sikora, eds Mobilizing IPM for sustainable banana production in Africa pp 9-22. Proceeding of a workshop held in Nelspruit, South Africa, $23-28$ November, 1998 INIBAP, Montepellier, France 1999.

[5] Geir, P.W. Physiological age of codling moth female (Cydia pomonella L.) caught in bait and light traps. Nature, London, 1960. 185:709.

[6] IITA (international Institute of Tropical Agriculture). Yam research at IITA: 1971 - 1993. Crop Improvement Division, Root and Tuber Improvement Program. IITA, Ibadan, Nigeria. 1995, 38 pp.

[7] IITA (International Institute of Tropical Agriculture). Tuber and Root Crops Information System. In: a strategic Action Plan for Root and Tuber Crops for ENSO Mitigation in Eastern and Southern Africa. IITA, Ibadan, Nigeria. 1998, pp. $74-77$.

[8] Inyang, U.E and S.O. Emosairue. The potential threashold level, relative abundance, life cycle and control of bana weevil, cosmopolites sordidus Germar (Coleoptera: Curculiobnidae) on plantain in Uyo, Akwa Ibom State, Nigeria. Ph.D thesis, Michael Okpara University of Agriculture, Umudike. 2004. 295pp.

[9] Kumar, R. Insect control with special reference to African Agriculture. Edward Arnold Publisher Limited, London. 1984 298pp.
[10] N.M.A. Nigerian Meteorological Agency, Delta State Meteorological Inspectorate Asaba, 2005.

[11] Nweke, F.I. Ugwu, B.O. Asadu, C.L. and Ay, P. Production costs in yam-based cropping systems of souther-western Nigeria. resource and crop Management Division. Research Monograph No. 6 IITA, Ibadan Nigeria, 1997. 29pp.

[12] Onwueme, I.C. The tropical Root and Tuber crops: Yams, Cassava Sweet potato and Cocoyams. John Wiley and Sons New York 1978. 234pp.

[13] Southwood, T.R.E Ecological Methods. $2^{\text {nd }}$ eds. Chapman and Hall, London. 1968

[14] Taylor, T.A. Studies on the Nigeria yam beetles II. Bionomics and control. Journal of West African Science Association 1964. 9:13 - 31.

[15] Tobih, F.O. and Emosairue, S.O. Assessment of yam beetle damage under screen house condition. The Nigerian Agricultural Journal. 2006 37:50 - 52.

[16] Tobih, F.O. and Emosairue, S.O. Damage by yam beetle, Heteroligus meles (Coleoptera: Dynastidae) under different population in yam cropping system. Global Journal of Pure and Applied Sciences 2008 4(1):5-8.

[17] Tobih, F.O., Emosairue, S.O. and Okonmah, L.U., Studies on the occurrence and damage by yam tuber beetles (Heteroligus spp) in Aniocha and Oshimili areas of Delta State, Nigeria. Journal of Central Eurpean Agriculture. 2007 8(1):129 - 134.

[18] Tobih, F.O., Emosairue, S.O. and Omoloye, A.A. Evaluation of carbofuran, chlorphyriphos and endosulfan for the control of yam beetles, Heteroligus spp. (Coleopetera: Dynastidae), in Delta State, Nigeria. Nigerian Journal of Entomology. 2007 24:76 - 81.

[19] Umeozor, O.C. Evaluation of Furadan as a substitute for Aldrin in the control of the yam Tuber Beetles, Heteroligus meles billb and $H$. appius Burm, (Coleoptera: Dynastidae) Nigeria Journal of Entomology. 1998 15:100 - 106. 